\title{
Psikolojik Güçlendirme Çalışanların Sosyal Kaytarma Davranışlarını Azaltır mı?
}

\section{Does Psychological Empowerment Decrease Social Loafing Behaviors of Employees?}

\author{
Mustafa KESEN, Adnan Menderes Üniversitesi, Türkiye, m_kesen@hotmail.com
}

\begin{abstract}
Öz: Organizasyonların vazgeçilmezlerinden olan grup çalışmasının her zaman bireysel performansı arttırmasını beklemek zordur. Grup içerisinde çeşitli nedenlerden dolayı bazı bireylerin çabalarını azaltmaları mümkündür. Bu durum literatürde sosyal kaytarma olarak ifade edilmiştir ve bu durumu engelleyici uygulamaların neler olabileceği birçok çalıșmada ele alınmıștır. Bu çalıșmada ise psikolojik güçlendirmenin sosyal kaytarma problemine çare olup olamayacağı araştırılmıştır. Çalışma Elazı̆̆ ve Malatya'da faaliyet gösteren 5 farklı imalat firmasının çalışanları üzerinde uygulanmıştır. Toplamda 175 çalışandan anket yöntemiyle elde edilen veriler güvenilirlik analizi, doğrulayıcı faktör analizi, korelasyon ve regresyon analizleri ile incelenmiştir. Elde edilen sonuçlara göre psikolojik güçlendirme boyutlarından anlamlılı, sosyal kaytarma davranışlarını azaltmada önemli bir role sahiptir. Psikolojik güçlendirmenin diğer boyutlarl olan etki, yetkinlik ve özerkliğin ise sosyal kaytarmayı anlamlı olarak etkilemediği görülmüştür.
\end{abstract}

Anahtar Kelimeler: Psikolojik Güçlendirme, Sosyal Kaytarma, Alan Araştırması

Abstract: It is difficult for group working which is indispensable for organizations to always increase individual performance. It is possible for some individuals within groups to decrease their effort due to different reasons. This phenomenon is called as social loafing in the literature and many studies have investigated the applications that can prevent this situation. In this study it is investigated that whether psychological empowerment can be a solution for the problem of social loafing. This study was applied on the employees of 5 manufacturing companies operating in the provinces of Elazı ̆̆ and Malatya. Data gathered from 175 individuals via questionnaires were analyzed with reliability analysis, confirmatory factor analysis, correlation analysis and regression analysis. According to the results, a dimension of psychological empowerment which is meaning plays an important role in decreasing social loafing behaviors of employees. Other dimensions of psychological empowerment which are impact, competence and self-determination are observed that they are not significantly affecting social loafing.

Keywords: Psychological Empowerment, Social Loafing, Field Study

\section{Giriş}

Organizasyonların en belirgin özelliklerinden birisi bir araya gelmiş insan kaynağından oluşmaları ve grupsal faaliyetlerin yoğun olmasıdır. Dolayısıyla grup veya takım çalışması uzun yıllardır araştırmacılar tarafindan üzerinde çalışılmakta olan bir konudur. Grup çalışması organizasyonda çalışanların bireysel çabalarını ve sonuçta da performanslarını arttırabilmektedir. Fakat bazı çalışmalar (Karau ve Williams, 1997; Williams v.d., 1981) bunun aksini ortaya koymakta, bireylerin grupsal aktivitelerde bireysel aktivitelere göre daha az çaba harcadığını belirtmektedir. Sosyal psikoloji çalışmalarında karşılaşılan ve sosyal kaytarma olarak adlandırılan bu kavramı Latane v.d. (1979) sosyal bir hastalık olarak tanımlamaktadır. Onlara göre sosyal kaytarma bireysel, sosyal ve toplumsal anlamda birçok negatif sonuç doğurmaktadır. Hatta Aggarwal ve O’Brien (2008)'e göre sosyal kaytarma grup etkinliğini azaltan en önemli faktör olarak gösterilmektedir.

Kolektif çalışmanın daha çok vurgulandığı günümüzde "başkalarının sırtından geçinmek" olarak da ifade edebileceğimiz işten kaytarma problemine çareler bulunmaya çalışılmaktadır. Bu çareler arasında grup kaynaşmasını sağlama ve grup büyüklüğünü azaltma (Ilgın, 2013), karşılıklı bağımlı çalışmanın mümkün olduğunca azaltılması (Liden v.d., 2004:285-304) ve grup motivasyonunu arttırma (Rothwell, 2004) gibi faktörler say1lmaktadır.

Sosyal kaytarmanın bireysel ve sosyal psikoloji ile ilişkili olduğu da düşünülebilir. Sosyal anlamda gruptaki diğerlerinin daha az çaba sarf ettiğini gören bireylerin kendi çabalarını da azaltmaları ve böylece grubun ortak psikolojisinin negatif yönde etkilenmesi mümkündür. Diğer taraftan psikolojik olarak zayıf ve güçsüz durumda olanların grubun etkinliğine yapacağı katkı azalabilmektedir. Sosyal kaytarmanın muhtemel nedenlerini açıklamaya çalışan ve Latane (1981) tarafından ileri sürülen "sosyal etki" teorisine göre bir bireyin diğer bireylerin gerçek, sezdirilmiş veya hayali varlıkları veya faaliyetlerinin bir sonucu olarak, psikolojik durumunda, öznel duygularında, güdülerinde, duygulanımlarında, bilişlerinde, inançlarında ve davranışlarında önemli düzeyde değişikliklerin meydana gelebileceği ifade edilmiştir (Ilgın, 2013).

Psikolojik güçlendirme ile kaytarma arasındaki ilişkiyi inceleyen bir alan araştırmasının henüz olmaması bu çalışmanın önemini arttırmaktadır. Bu çerçevede bu çalışmanın amacı sosyal kaytarma literatürüne katkıda bulunarak psikolojik güçlendirmeyi kaytarmaya bir çözüm olarak önermektir. Bir ön kabul olarak psikolojik güçlendirmenin çalışanların sosyal kaytarma davranışlarını azaltacağı düşünülmüştür. Araştırmada öncelikle konu ile ilgili literatür taraması yapılmış, çalışmanın tasarımı, uygulanması ve anket verilerinin analizi aşamaları ele alınmış ve ardından elde 
edilen analiz sonuçlarına göre ön kabul revize edilmiştir. Sonuçların işletme yöneticilerine, araştırmacılara, çalışanlara ve ilgili diğer kişi ve kuruluşlara önemli ipuçları sunacağı düşünülmektedir.

\section{Kavramsal Çerçeve ve Hipotezler}

\subsection{Sosyal Kaytarma}

Sosyal kaytarma ile ilgili ilk araştırmanın 1913 yılında Fransız ziraat mühendisi Ringelmann tarafından yapıldığı bilinmektedir (Kravitz ve Martin, 1986). Bir halat çekme deneyinde bireylerin bireysel ve toplu olarak halat çekmesi istenmiş ve toplu halat çekimindeki birey başına düşen kuvvetin tek başına iken uyguladıkları kuvvetten daha az olduğu gözlemlenmiştir. Dolayısıyla sosyal kaytarma kavramı ortaya çıkmış ve kimlerin, neden, nasıl kaytardığının araştırılması önemli hale gelmiştir. Sosyal kaytarma davranışı, işgörenlerin bir grup içerisinde, birlikte çalıştıkları diğer bireylerle karşılaştırıldığında işe yönelik süreçlerde motivasyon düzeylerinin ve çaba gösterme eğilimlerinin azalması olarak tanımlanmaktadır (Høigaard vd., 2010 ; Kanten, 2014:12). Bu konuda yapılmış birçok çalışmanın sonucuna göre sosyal kaytarma çeşitli görev ve topluluklarda geçerli olan güçlü bir olgudur (Karau ve Williams, 1997:156-168). Şeşen ve Kahraman'ın (2014) ifadelerine göre grup içerisinde bireyin çabasının belirlenememesi sosyal kaytarmaya etki eden en önemli sebeplerdendir.

Sosyal kaytarma grup üyelerini hayal kırıklığına uğratma, bireylerin daha az üretken olması, bireysel yeteneklerin ortaya çıkmasının engellenmesi, tükenmişlik, düşük katılım gibi negatif sonuçlar doğurmaktadır (Harkins ve Petty, 1982). Araştırmacılara göre grup üyelerine ödül veya ceza verilmemesi bireyleri sosyal kaytarma davranışına itebilmektedir ve böylece kendisine herhangi bir zarar gelmeyeceğini düşünen çalışan daha az çaba sarf etmektedir (George, 1992). Diğer taraftan kişilik farklılıklarının bazı bireyleri diğerlerine göre daha fazla kaytarmaya ittiğini ifade eden birçok çalışma bulunmaktadır (bakınız: Bolin ve Neuman, 2006; Morgeson v.d., 2005). Örneğin diğerlerinden daha iyi olduğuna inanan bireyler (Charbonnier v.d., 1998), bilişsel ihtiyaçları daha az olanlar (Smith v.d., 2001) veya motivasyonu daha az olan bireyler (Hart v.d., 2004) diğerlerine göre daha fazla kaytarma davranışı sergilemektedirler. Kugihara (1999)'nın çalışmasına göre de kadınlar erkeklerden daha az kaytarma davranışı sergilemektedir.

Steiner (1972) grup içerisinde bireylerin performans düşüklüğünü çalışan motivasyonun düşmesine veya bireyler arası koordinasyon kaybına bağlamıştır. Webb (1997)'e göre kaytarma gönülsüz bir davranıştır ve verilen görevleri yerine getirmede kendini yetersiz hissetme veya kendini yeteneksiz görme sonucunda ortaya çıkmaktadır. Kendini yetersiz görme bireyleri projeye yapacakları katkının grup tarafından fark edilmeyeceği inancına itebilmektedir (Dommeyer, 2007).

\subsection{Psikolojik Güçlendirme}

Personel güçlendirme, hızlı bir şekilde değişen pazar ve çevre koşullarının, değişen ve gelişen personel niteliklerinin ve beklentilerinin, farklılaşan ve sürekli artan müşteri beklentilerine hızlı ve etkin şekilde cevap verme ihtiyacının ortaya çıkardığı yeni yönetim kavramlarından biridir (Doğan, 2003:165). Çalışanların işleri başarabilme yeteneklerini azaltacak sınırlamaların ortadan kaldırılması ve onların işlerini kendilerinin yapabilmelerinin sağlanması günümüzde daha önemli hale gelmiştir (Jefkins, 1995:37).

Hales ve Klidas (1998:89), güçlendirmeyi, enformasyonun, bilginin ve gücün alt kademedeki işgörenlerle paylaşılması şeklinde tanımlanmaktadır. Bazı çalışmalarda güçlendirme, üst yönetim tarafından, çalışanlara yetki ve sorumluluk verilmesi, çalışanların ise örgütsel hedef ve değerlere ulaşabilmek için işine sahip çıkması ve sorumluluğu üstlenmesi olarak açıklanmıştır (Eade,1993; Besterfield vd., 1999).

Günümüz modern yönetim kavramlarından psikolojik güçlendirme ise örgütteki güçlendirme müdahalelerinin başarılı olması için çalışanlar tarafından deneyimlenmesi gereken psikolojik bir durumdur (DeCicco vd., 2006:51; Kluska vd., 2004:116). Spreitzer'a $(1995 ;$ 1996) göre güçlendirmeyi, örgütün çalışanların güçlendirilmesi adına yaptığı uygulamalara dayalı olarak ortaya çıkan objektif gerçeklerden çok, çalışanların bu uygulamalara ilişkin algıları şekillendirmektedir.

Thomas ve Velthouse (1990:666-681) geliştirdikleri bilişsel model çerçevesinde psikolojik güçlendirmeyi çalışanların kendisini güçlendirilmiş hissedip hissetmediğine ilişkin algısı olarak tanımlamışlar ve güçlendirmenin çalışanları motive etmede önemli bir yeri olan bilişsel değişim ile ilgili olduğunu ifade etmişlerdir. Onların geliştirdiğgi motivasyonel veya psikolojik güçlendirme yaklaşımı, bireylerin işlerinde tecrübe ettikleri bilişsel veya psikolojik durumlarına odaklanmaktadır. Bu teori çalışanların işyerinde karşılaştığı kişi veya olaylarla başa çıkmaya çalışırken kendi güçlerini nasıl algıladıkları üzerinde durmaktadır. Bununla birlikte işe bağlılığı ve iş doyumunu arttırmak için açık iletişimi, amaçlara odaklanmayı ve geri bildirimlerde bulunmayı önermektedir (Khany ve Tazik, 2015). Bu çerçevede Thomas ve Velthouse (1990) anlam, yetkinlik, otonomi (seçim) ve etki boyutlarını içeren bir psikolojik güçlendirme modeli geliştirmişlerdir. Bu boyutlar şöyle açıklanmaktadır:

Anlam: Bireyin verilen görevi içsel olarak önemsemesi (Thomas ve Velthouse, 1990: 672) ve iş hedef ve amaçlarının değerinin bireyin kendi ideal ve standartlarına göre değerlendirilmesidir (Spreitzer,1995). Düşük anlamlılık düzeyi, önemli olaylara karşı ilgisizlik, soğukluk ve umursamazlık gibi olumsuz sonuçlar doğurabilirken yüksek 
anlamlılık düzeyi örgütsel bağlılı̆̆ı, katılımı ve işe yönelik gayreti arttırabilir (Thomas ve Velthouse, 1990: 673; Spreitzer v.d., 1997: 683). İşlerin çalışanlara anlamlı gelmesi ile çalışanlar yaptıkları işi önemsemekte ve işlerinin önemli olduğunu düşünmektedirler. Görevin çalışan için anlam ifade etmemesi durumunda ise çalışanın örgüte olan bağlılığının azalacağı, olaylara karşı ilgisiz kalacağı ve görevinde dikkat sorunu yaşayacağı düşünülmektedir (Arslantaş, 2007). Bireyin verilen görevi başarı ile yerine getireceğine inancı, bireyin kendisine daha fazla güvenmesine neden olurken bu sonucun mesleki yeteneklerine de olumlu yansıması söz konusudur (Doğan ve Demiral, 2009: 51).

Yetkinlik: Çalışanların, işleriyle ilgili faaliyetleri gerçekleştirecek kapasiteye sahip olup olmamalarına dair inançlarıyla ilgilidir. Bireyin kendini işi konusunda yeterli hissetmesi performans yeteneklerine güvenmesi anlamına gelmektedir (Spreitzer vd.,1997: 682). Bireyin kendi becerisine inanması durumunda birey inisiyatif kullanacak, daha fazla çaba gösterecek ve engellerle karşılaştığında ortadan kaldırmak için gayret sarf edecektir (Arslantaş, 2007:230). İşgörenler sahip oldukları yetkinliklerinden ne kadar eminseler, o kadar yeteneklerini kullanacakları faaliyetlere girmeye istekli olacaklardır (Emet, 2006:11).

Özerklik: Karar verme özgürlüğünü ifade eden özerklik (otonomi), çalışanların işleri üzerinde kontrol sahibi olmaları ile ilgilidir. Bireyin işindeki davranışlarında, süreçlerde, yeni girişimlerinde başkalarından bağımsız olmasını ifade eder ve bireyin faaliyetlerinde sorumluluk almasının önemi üzerinde durur (Arslantaş, 2007:230). İş tatmini ile ilgili olan özerklik psikolojik bir ihtiyaçtır ve içsel motivasyonun önemli bir parçasıdır (Spreitzer vd.,1997). Birey seçim hakkı ile kendi geleceğini belirleyebilmekte ve hür iradesini ortaya koyabilmektedir (Doğan, 2006:79).

Etki: $\mathrm{Bu}$ boyut, kişilerin iş yapma süreçlerinde istenen etkileri oluşturacak farklılıkları yapabilme derecesini ifade eder (Thomas ve Velthouse, 1990: 672). Etki boyutunda kişi kendi işi üzerinde değil örgütün tümünü ilgilendiren sonuçlar üzerinde kontrol sahibi olma duygusu içindedir (Spreitzer vd., 1997). Bireyin işin stratejik, yönetsel veya operasyonel çıktıları üzerindeki etki derecesi ile ilgilidir (Ashforth, 1989). Çalışanların işyerlerinde bir iz bırakabilme ve örgütün onların fikirlerini ciddiye alma düzeyini gösterir (Tolay v.d., 2012). Kişi, çıktıların dışsal faktörler aracılığı ile kontrol edildiğini düşünüyorsa, bu durumda çıktıları etkileme konusunda fazla bir etkiye sahip olmadığını düşünecektir (Luthans, 1995:162). Özerklik, işgörenin kendi işi üzerindeki kontrol duygusu ile ilgili iken etki işgörenin örgütsel sonuçlar üzerindeki kontrol yetisine işaret etmektedir (Spreitzer, 1995).

$\mathrm{Bu}$ dört boyut psikolojik güçlendirmenin genel yapısını oluşturmaktadır ve bu boyutlardan bir veya birkaçının eksikliği durumunda psikolojik güçlenme zayıflamaktadır (Spreitzer, 1995). Tüm boyutların yüksek düzeyde algılanması ise bireyin içsel motivasyon düzeyini arttırarak çalışanın güçlendirilmiş hissetmesini sağlamaktadır (Şen, 2008:29).

\subsection{Sosyal Kaytarma ve Psikolojik Güçlendirme İlișkisi}

Yöneticilerin önemli görevlerinden biri bireysel ve grupsal performans artışını sağlamaktır. Yönetici, çalışanlarını güçlendirmek için bir çaba göstermiyorsa çalışanların güçlendirildiğine ilişkin bir tanımlama yapmak doğru olmaz (Thomas ve Velthouse, 1990:672-673). Personelin verimliliğini arttırma faaliyetleri ile ilgilenirken yöneticilerin çözmek zorunda kalabilecekleri sorunlardan bir tanesi de sosyal kaytarma problemi olabilir ve dolayısıyla yöneticiler bu problemi çözmek için sorumluluk almalıdırlar (Alnuaimi v.d., 2010). Çalışanların motivasyonlarının azalması ve psikolojik olarak zayıf düşmesi kaytarmanın olası nedenlerindendir. Thompson ve Thornton (2007), sosyal kaytarmanın psikolojik bir yönü olduğunu ifade etmiş ve bireyin çabasındaki azalmanın diğer grup bireylerince fark edilmeyeceği yönündeki bireysel algının, psikolojik ruh halinin bir yansıması olabileceğini belirtmişlerdir. Arevalillo-Herráez (2014) de öğrenciler üzerinde yaptığı bir araştırmanın sonuç kısmında, işbirliğinin gerekli olduğu ortamlarda sosyal kaytarma davranışları sergileme nedenlerinin psikolojik perspektiften de ele alınabileceğini ifade etmiştir.

Bireylerin psikolojisi ile sosyal kaytarmanın bu potansiyel ilişkisinden yola çıkarak yöneticilerin çeşitli psikososyal araçlarla çalışanlarını desteklemeleri gerektiği ve böylece bilinçli veya bilinçli olmayan kaytarmaların önüne geçebilecekleri ifade edilebilir. Örneğin bireylerin gösterdikleri çabaların yöneticiler tarafından fark edileceğine inandırılmaları bu durumu engelleyebilir (Kanten, 2014:14) ve çalışanlar bireysel sorumluluklarını daha fazla yerine getirebilirler.

Stark ve diğerlerine (2007) göre sosyal kaytarma sadece durumsal bir olgu değil aynı zamanda bireylerin psikolojileri ile de ilgilidir. Bireylerin içinde bulunduğu psikolojik durumun sosyal kaytarmayı etkilemediğini ifade etmek zordur. Dolayısıyla sosyal kaytarma bireylerin çok karmaşık olan psikolojilerinin bir fonksiyonudur (Liden v.d., 2004).

Güçlendirilmiş çalışanlar, sorumluluğa sahip olma hissine ve neyin nasıl yapılması gerektiği üzerinde güce sahiptirler (Tazegül, 2001:9). Çalışma grubu içerisinde gelişen takım çalışması ve takım çalışmasına uyum, güçlendirmenin özellikle çalışanlar açısından katkılarına ilişkin belli başlı unsurlarındandır (Mirzehanlı, 2001:101). Diğer taraftan güçlendirme, yüksek derecede işbirliği ile sonuçlanmaktadır (Somuncuoğlu, 2013). Psikolojik güçlendirme sayesinde bireysel sorumluluk bilincinin, işbirliğinin ve takım çalışmasına uyumun daha da artması ile sosyal kaytarma davranışlarının azalacağına inanılmaktadır.

Psikolojik güçlendirme, çalışanların işlerinde başarıya ulaşma yeteneklerini arttırma ile ilgilidir. Artan bireysel başarım yeteneğiyle birlikte çalışanların ulaşabilecekleri özgüven ve işe bağlanma duygularının çalışanların sosyal çevre ilişkilerine ve işteki grupsal faaliyetlerine olumlu katkı yapması beklenmektedir. Bununla birlikte psikolojik 
güçlendirme ile bireyler, görevlerini kendileri yapabilir hale gelecek ve sosyal kaytarma davranışını sergilemeye gerek duymayacaklardır. Çünkü sosyal kaytarmanın önemli sebeplerinden bir tanesi çalışanların gruptaki görevlerini başarıyla yerine getirme noktasında kendilerini yetersiz görmesidir (Webb, 1997) ve psikolojik güçlendirme ile çalışanlar görevlerini yerine getirmede kendilerini yeterli hissedebileceklerdir.

Psikolojik güçlendirmenin alt boyutlarından her biri çalışanların sosyal kaytarma davranışlarını daha az sergilemelerini sağlayabilir. Örneğin işler çalışanlara anlamlı geldikçe işi daha fazla önemseyecekler ( Lee ve Koh, 2001) ve işe atfettikleri değer daha da artacaktır. Karau ve Williams’ın (1997) çalışmasında, anlamlılığı düşük olan bir görevde çalışırken, bireylerin performansı düşük bir diğer birey için sosyal telafi gerçekleştirmedikleri ortaya çıkmıştır. Yine Karau ve Williams (1993) görevin önemi arttıkça sosyal kaytarmanın azaldığını ve görevin anlamlılığı yüksek düzeyde olduğunda sosyal kaytarmanın ortadan kalkabileceğini ifade etmişlerdir (Ilgın, 2010). Böylece çalışanlar işlerini grup arkadaşlarına bırakmak istemeyecek, kendileri işlerle bizzat ilgilenecek ve işten daha az kaytaracaklardır. Bu amaçla ilk hipotez şöyle kurulmuştur:

\section{H1:Psikolojik güçlendirme boyutlarından anlamlılık sosyal kaytarmayı negatif ve anlamlı olarak etkiler.}

Çalışanları işten soğutan önemli hususlardan biri işleri yapabilecek kapasite ve yeteneklere sahip olmadıklarını düşünmeleridir. Böyle bir durumda bireyler sorumluluklarını yerine getiremeyerek işleri başkalarından bekleyecek ve kaytarmaya daha meyilli olacaklardır. Bireyin kendi becerisine inanması durumunda ise, bireyin inisiyatif kullanması, daha fazla çaba göstermesi ve engellerle karşılaştığında ortadan kaldırmak için gayret etmesi beklenmektedir (Arslantaş, 2007). Bu bağlamda bireyin kendi becerisine olan inancının önem taşıdığı (Thomas ve Velthouse, 1990) yetkinlik boyutunun kaytarma ile ters orantılı bir ilişki içerisinde olduğu düşünülmektedir:

\section{H2: Psikolojik güçlendirme boyutlarından yetkinlik sosyal kaytarmayı negatif ve anlamlı olarak etkiler.}

Bireyler kendilerini görevlerinde diğerlerine daha fazla bağımlı algıladıkça, işlerinde kişisel başarı elde ettikleri hissine sahip olabilmeleri daha da güçleşebilmektedir (Manz ve Angle, 1986). Benzer şekilde, koşullar bireysel başarılar sergilemelerine izin vermediğinde; bireyler çaba göstermeme eğilimi içine girmektedirler (Jones, 1984:684695; Williamson, 1975). İşlerde özerklik arttığında bireyler çabalarının diğer grup üyelerininkinden ayırt edilebileceğine inanmakta ve fark edilmenin çabaları arttırmaya değer olacağına inanabilmektedirler (Liden v.d., 2004:285-304). Bu bilgilerden yola çıkarak diğer hipotez şöyle kurulmuştur:

\section{H3: Psikolojik güçlendirme boyutlarından özerklik sosyal kaytarmayı negatif ve anlamlı olarak etkiler.}

Aldıkları karar ve yaptıkları işlerin işletmeye olumlu etkisinin olduğunu gören bireyler, grup içerisindeki mevcut çabalarından vazgeçmeyecek ve belki de daha fazlasını ortaya koymak için çalışacaklardır. Diğer taraftan iş sonuçlarına direkt etkisi olan karar, toplantı ve programlara sınırlı katılım çalışanları güçsüz düşürmektedir (Conger ve Kanungo, 1988). Gruba kendi katkılarının anlamlı bir fark oluşturmayacağına çünkü grup için çalışan birçok bireyin olduğuna inanan bireyler daha çok kaytarmaktadırlar (bakınız: Petty v.d.,1980). Bu sebeple işleri sırasında fark oluşturabilen bireylerin daha az kaytarmaya yönelmeleri beklenebilir. Bu bilgiler 1şı̆̆ında geliştirilen hipotez şöyledir:

\section{H4: Psikolojik güçlendirme boyutlarından etki sosyal kaytarmayı negatif ve anlamlı olarak etkiler.}

Alanyazın incelendiğinde çok boyutlu modellerin yanı sıra tek boyutlu modellerin de uygulamada kullanılabileceği görülmektedir. Çok boyutlu modellerin belli bir teoriye dayanmaması eleştirilmekle beraber (Aktaş, 2003: 5) bu modellerin daha çok tercih edilmesinin nedeni; (i) incelenen ana değişkenin hem tüm özelliklerini hem de bu özellikler arasındaki ilişkiyi ölçmeye imkânı vermesi (Altman, 1983: 101) ve (ii) tek boyutlu modellere göre öngörü gücünün daha yüksek çıkması (Göktan, 1981: 65) olarak gösterilmektedir. Diğer taraftan tek boyutlu modellerin çok boyutlu modellere kıyasla uygulama kolaylığı açısından daha üstün olduğu da ifade edilmektedir (Aktaş, 2003: 5). Uygulamada tek boyutlu ve çok boyutlu yapıları kullanmada farklı örneklerle karşılaşıldığından bu çalışmada her ikisinin de uygulanması benimsenmiştir. Dolayısıyla psikolojik güçlendirme değişkeni dört alt boyuttan oluşan bir bütün olarak da ele alınmış ve sosyal kaytarma üzerindeki etkisi inceleme konusu yapılmıştır. Daha önce geliştirilen alt boyutlu hipotezlere ek olarak şu hipotez geliştirilmiştir:

H5:Psikolojik güçlendirme sosyal kaytarmayı negatif ve anlamlı olarak etkiler. 


\section{Araştırmanın Bulguları}

\subsection{Araştırmanın Amacı ve Modeli}

$\mathrm{Bu}$ araştırmanın amacı psikolojik güçlendirmenin sosyal kaytarma davranışı üzerindeki etkilerini belirlemektir. Psikolojik güçlendirme ile sosyal kaytarma arasındaki muhtemel ilişkiyi ortaya koyan araştırmanın modeli ve hipotezleri Şekil 1'de görüldüğü gibidir.

Araştırmada elde edilen verilere araştırma modeli doğrultusunda belirli analizler yapılmıştır. Bu doğrultuda araştırma modelinde yer alan tüm ölçeklere doğrulayıcı faktör analizleri yapılmış, güvenilirlikleri test edilmiş ve değişkenler arası ilişkiyi belirlemek için korelasyon analizi yapılmıştır. Araştırma hipotezlerinin test edilmesinde ise regresyon analizi uygulanmıştır.

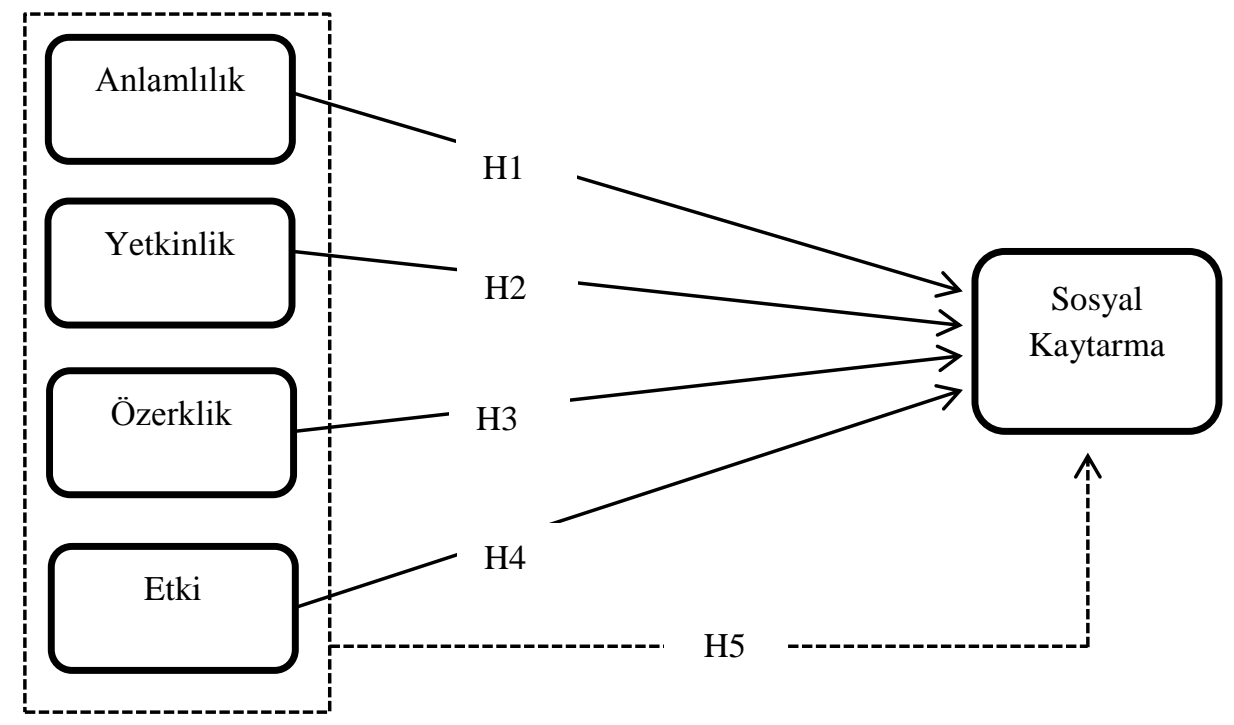

Şekil 1. Araştırmanın Modeli ve Hipotezler

\subsection{Araştırmanın Kapsamı ve Yöntemi}

$\mathrm{Bu}$ çalışma Malatya ve Elazı̆̆ organize sanayi bölgesinde faaliyet gösteren firma çalışanları üzerinde uygulanmıştır. Doğu Anadolu Bölgesi'nin önemli şehirlerinden Malatya'da organize sanayi bölgesinde 200'e yakın firma faaliyet göstermektedir ve sanayi üretiminin artışıyla birlikte kentte olumlu yönde bir sosyo-ekonomik dönüşüm başlamıştır (MALORSA, 2015). Elazığ ili ise hizmet sektörü ile birlikte sanayi sektöründe ekonomik potansiyeli bulunun bir şehirdir ve organize sanayii bölgelerinde toplamda 100'den fazla firmanın çeşitli alanlarda üretimlerini sürdürmesi bunun somut göstergelerindendir (Elazığ TSO, 2015). Dolayısıyla üretim sektöründe bölgenin lokomotifi olan bu iki şehirde bilimsel çalışmalara katkıda bulunacak araştırmalar yapılmasının önemli olduğu düşünülmektedir.

Malatya ve Elazığg'da bulunan 5 firma ile irtibata geçilmiş ve çalışanlara anketlerin uygulanması sağlanmıştır. Bu firmalardan ikisi Malatya'da tekstil sektöründe faaliyet gösterirken Elazı̆̆'daki sanayi bölgesinde faaliyet gösteren firmalardan ikisi 1sı sektöründe, diğeri ise metal sanayiinde üretimlerine devam etmektedir. Üretim sektöründe yaygın görülen uygulamalardan birisi üretim takımlarının oluşturulmasıdır ve bu takımlarda her bir bireyin grup çalışmalarına katkısına önem verilmektedir. Bu sebeple üretim sektörü çalışanları üzerinde yapılacak araştırmaların sosyal kaytarma çalışmalarına önemli katkılar sağlayabileceği düşünülmektedir.

Kolayda örnekleme metodu ile yapılan bu araştırma, çalışanlara anketlerin elden verilmesi suretiyle uygulanmış ve doldurmaları için yeterli zaman verildikten sonra anketler geri toplanmıştır. Toplamda 191 anket geri alınmış ve analize uygun olmayan 16 anket çıkarılarak 175 anket üzerinden çalışmalara devam edilmiştir.

Araştırmaya katılan çalışanlara ilişkin demografik veriler Tablo 1'de gösterilmiştir. Araştırma örnekleminin \% 77'si (n=136) alt düzey çalışanlardan oluşmaktadır. Çalışanların \%34'ü (n=60) 1 ile 5 yıl süredir şu an bulundukları firmada çalışmaktadır. Örneklemin \% 54’ü $(n=95)$ erkekler oluşmaktadır. Araştırmaya katılanların \% 42’si (n=73) 2635 yaş aralığındadır ve katılımcıların \% 47'si $(n=82)$ lise ve alt kademe okullardan mezundur. 
Tablo 1. Katılımcılara İlişkin Demografik Veriler

\begin{tabular}{lcc} 
Cinsiyet & Frekans & \% \\
\hline Erkek & 95 & 54 \\
Kadın & 80 & 46 \\
Pozisyon & Frekans & \% \\
\hline Alt düzey çalışan & 136 & 77 \\
Yönetici & 39 & 23 \\
Mevcut firmada tecrübe & Frekans & $\%$ \\
\hline 1 y1ldan az & 30 & 17 \\
1-5 yil & 60 & 34 \\
6-10 y1l & 51 & 29 \\
$11-20$ yıl & 25 & 14 \\
20 yildan fazla & 9 & 6 \\
Yaş & Frekans & $\%$ \\
\hline 25'ten az & 51 & 29 \\
26-35 & 73 & 42 \\
36-45 & 44 & 25 \\
45'ten fazla & 7 & 4 \\
Eğitim & Frekans & \% \\
\hline Lise ve alt kademe & 82 & 47 \\
Önlisans & 53 & 30 \\
Lisans/Lisansüstü & 40 & 23
\end{tabular}

\subsection{Kullanılan Ölçekler}

Çalışmada literatürde genel kabul görmüş psikolojik güçlendirme ve sosyal kaytarma ölçekleri kullanılmıştır. Anketin birinci bölümü psikolojik güçlendirme, ikinci bölümü ise sosyal kaytarmayı ölçen sorulardan oluşmaktadır. Son bölümde ise demografik değişkenlerle ilgili sorular sorulmuştur. Demografik değiş̧enler dişındaki tüm soruları cevaplamada 5'li Likert ölçeğinden (1=kesinlikle katılmıyorum; 5=kesinlikle katılıyorum) yararlanılmıştır.

Psikolojik güçlendirme faktörlerinin ölçülmesinde Spreitzer'in (1995) oluşturduğu ölçekten yararlanılmıştır. Ölçeğin Türkçe 'ye uyarlanmış hali Somuncuoğlu (2013)'nun çalışmasından alınmıştır ve ilgili çalışmada ölçeğin geçerli ve güvenilir bir ölçek olduğu belirtilmiştir. Psikolojik güçlendirme ölçeği anlam, etki, yetkinlik ve özerklik olmak üzere dört alt boyuttan oluşmaktadır ve alt boyutları oluşturan faktörlerin her biri 3'er soru ile ölçülmüştür. Boyutların güvenilirlik katsayısı için Cronbach's Alfa değeri hesaplanmış ve anlamlılık boyutu için .750, etki boyutu için .741, özerklik boyutu için .690 ve yetkinlik boyutu için .713 değeri bulunmuştur. Güvenilirlik, bir değişkeni ölçmek için sorulan soruların ne derece bilinçli olarak cevaplandığının bir göstergesi olarak değerlendirildiğinden (Özdoğan ve Tüzün, 2007: 644), özerklik ile ilgili soruların diğer boyutların sorularına göre nispeten daha az bilinçle cevaplandırılmış olabileceği düşünülmektedir. Diğer taraftan madde sayısının az olduğu ölçeklerde .690 güvenilirlik katsayısı kabul edilebilir sınırlar içerisindendir (Streiner, 2003; Nunnaly, 1978) ve özerklik boyutunun güvenilirliğinin yeterli seviyede olduğu düşünülmektedir. Genel olarak psikolojik güçlendirme ölçeği değerlendirildiğinde ise güvenilirlik değeri .838 olarak bulunmuştur. Bu değerlere göre ilgili ölçeğin güvenilirliğinin yeterli düzeyde olduğu gözlemlenmektedir.

Sosyal kaytarmayı değerlendirmek için Ilgın (2010)'ın Liden ve diğerlerine (2004) atfederek kullandığı 13 maddelik ölçekten yararlanılmıştır. Ilgın (2010) çalışmasında orijinal ölçeğin Türkçe'ye uyarlanmış halinin geçerlilik ve güvenilirlik çalışmasını yapmış ve yaptığı analizler sonucunda ölçeğin geçerli ve güvenilir olduğunu belirtmiş̧ir. Bu çalışmada da ölçeğin Cronbach's Alfa güvenilirlik değeri hesaplanmış ve 2 madde güvenilirliği düşürdüğünden ölçekten çıkarılmıştır. Kalan 11 maddenin güvenilirlik değeri ise ,869 olarak bulunmuştur.

\section{Bulgular}

Araștırma sonucunda elde edilen veriler SPSS ve Amos programlarında analize tabi tutulmuştur. Araştırmada kullanılan ölçekler için doğrulayıcı faktör analizleri yapılmıştır. Farklı alt boyutları içeren psikolojik güçlendirme ölçeği için birincil seviye doğrulayıcı faktör analizi yapılmıştır. Keşifsel faktör analiziyle de desteklenen faktör analizinde yetkinlik boyutuna ait bir maddenin değerleri düşürdüğü gözlemlenmiş ve maddenin çıkarılmasına karar verilmiştir. Geriye kalan 2 madde üzerinden yetkinlik boyutunun güvenilirlik analizi tekrar yapılmış ve ,711 değeri bulunmuștur. Ardından 11 maddelik psikolojik güçlendirme modeli üzerinde tekrar birincil seviye doğrulayıcı faktör analizi uygulanmıştır. Sosyal 
kaytarma ölçeği için ise birincil seviye tek faktörlü model analizi uygulanmıştır. Analiz sonuçları Tablo 2' de sunulmuştur.

Tablo 2. Doğrulayıcı Faktör Analizi Sonuçları (Uyum İyiliği İstatistikleri)

\begin{tabular}{|c|c|c|c|c|c|}
\hline Değișkenler & $\begin{array}{l}\text { CMIN/DF } \\
<5\end{array}$ & $\begin{array}{l}\text { RMR } \\
<, 08\end{array}$ & $\begin{array}{l}\text { GFI } \\
>, 85\end{array}$ & $\begin{array}{l}\text { CFI } \\
>, 90\end{array}$ & $\begin{array}{l}\text { IFI } \\
>, 90\end{array}$ \\
\hline $\begin{array}{l}\text { Personel } \\
\text { Güçlendirme }\end{array}$ & 3,20 & ,079 & ,886 & ,899 & ,901 \\
\hline Sosyal Kaytarma & 1,78 &, 053 & ,927 & ,951 & ,951 \\
\hline
\end{tabular}

Uyum iyiliği değer aralıklarının tabloda gösterilen kabul edilebilir standartlar seviyesinde veya üzerinde olduğu gözlemlenmektedir. Geçerlilik ve güvenilirlik analizlerinin ardından ölçeklere ilişkin elde edilen verilerin ortalamaları, standart sapmaları ve aralarındaki Pearson korelasyon katsayılarına bakılmıştır. İlgili değerler Tablo 3 'te görülmektedir.

Tablo 3. Ölçeklerin Tanımlayıcı İstatistikleri ve Maddeler Arasındaki Korelasyonlar

\begin{tabular}{llcccccc} 
Değiskenler & Ort. & S.S. & Anlamlılık & Etki & Özerklik & Yetkinlik & Sos.kaytarma \\
\hline Anlamlılık & 3,8514 &, 71171 & 1 & & & & \\
Etki & 3,5448 &, 79131 &, $191^{* *}$ & 1 & & & \\
Özerklik & 3,7524 &, 70004 &, $449^{* *}$ &, $497^{* *}$ & 1 & & \\
Yetkinlik & 3,9171 &, 75828 &, $817^{* *}$ &, $203^{* *}$ &, $502^{* *}$ & 1 & \\
Sos.kaytarma & 3,2665 &, 66409 &,$- 154^{*}$ &, 142 &, 115 &,- 088 & 1 \\
\hline
\end{tabular}

Tabloda görüldüğü gibi psikolojik güçlendirme faktörlerinin her biri arasında anlamlı seviyede ilişkiler bulunmaktadır. Sosyal kaytarma ile anlamlı ilişkisi bulunan tek faktör ise "anlamlılık" boyutudur. Modelde çoklu doğrusal bağlantı (multicollinearity) sorunu olup olmadığını belirlemek için tolerans ve VIF değerlerine bakılmış ve bağımsız değişkenler arası çoklu bağlantı olmadığını doğrulayan sonuçlar elde edilmiştir (Tolerans $>.2$, VIF $<10$ ).

Araştırma hipotezlerinin sınanması ve psikolojik güçlendirmenin sosyal kaytarma üzerindeki etkilerinin belirlenmesi amacıyla regresyon analizi uygulanmıştır. Analiz sonuçları Tablo 4'te gösterilmiştir. Araştırmada geliştirilen ilk 4 hipotez bir model üzerinde test edilmiştir. Model 1'de psikolojik güçlendirmenin boyutları anlamlılık, yetkinlik, özerklik ve etki, bağımsız değişkenler olarak belirlenmiştir. Elde edilen sonuçlara göre sadece anlamlılık boyutu bağımlı değişken sosyal kaytarmayı negatif ve anlamlı bir şekilde etkilemektedir ( $p<, 05$; Std. $\beta=-, 274)$. Diğer değişkenlerin ise anlamlı bir etkisi bulunmamaktadır. Dolayısıyla Hipotez 1 kabul edilmiş ve Hipotez 2,3 ve 4 ise reddedilmiştir.

Tablo 4. Regresyon Analizi Sonuçları

\begin{tabular}{|c|c|c|c|c|}
\hline \multirow[b]{3}{*}{ Bağımsız Değişkenler } & \multicolumn{4}{|c|}{ Bağımlı Değişken: Sosyal Kaytarma } \\
\hline & \multicolumn{2}{|c|}{ Model $1\left(\mathrm{R}^{2}=, 074 ; \mathrm{F}=3,407\right)$} & \multicolumn{2}{|c|}{ Model $2\left(\mathrm{R}^{2}=, 00 ; \mathrm{F}=, 009\right.$} \\
\hline & Std. $\beta$ & Sig. & Std. $\beta$ & Sig. \\
\hline Anlam &,- 274 &, $034 *$ & - & - \\
\hline Etki &, 102 & ,232 & - & - \\
\hline Özerklik &, 173 &, 075 & - & - \\
\hline Yetkinlik & 028 &, 834 & - & - \\
\hline Psikolojik Güçlendirme & - & - & 007 & ,925 \\
\hline
\end{tabular}

$\mathrm{N}=175 ; \mathrm{p}<.05$

Hipotez 5'i test etmek amacıyla 2. Model kurulmuştur, psikolojik güçlendirme bağımsız değişken olarak belirlenmiş ve bu değişkenin sosyal kaytarma üzerindeki etkisi incelenmiştir. Bulgulara göre psikolojik güçlendirme sosyal kaytarmayı anlamlı olarak etkilememektedir. Dolayısıyla Hipotez 5 reddedilmiştir. 


\section{Sonuç ve Değerlendirme}

Bu çalışmada psikolojik güçlendirmenin dört boyutu olan anlam, yetkinlik, özerklik ve etki ile bir bütün olarak psikolojik güçlendirmenin çalışanların sosyal kaytarma davranışları üzerindeki etkileri araştırılmıştır. Bu amaçla Elazı̆̆ ve Malatya'da 5 farklı imalat firmasında 175 kişi üzerinde uygulamalı bir araştırma yapılmıştır. Analize dahil edilen değişkenlerin sosyal kaytarma üzerindeki etkileri regresyon analizi vasıtasıyla açıklanmaya çalışılmıştır.

Araştırma bulgularına göre psikolojik güçlendirmenin boyutlarından anlamlılık sosyal kaytarmayı negatif yönde anlamlı olarak etkilemektedir. Yani istenmeyen kaytarma davranışlarını azaltmak veya yok etmek için anlamlılık değişkeni bir araç olarak kullanılabilir. Hung ve diğerlerinin (2009:266) de ifade ettiği gibi kaytaranlara işlerinin önemi anlatıldığında görev ve amaçlarını daha anlamlı göreceklerdir. Çalışanlar işlerinin önemini anladığında daha fazla çaba sarf edecek ve işi diğer grup üyelerine bırakmayacaklardır. İşler anlamlı hale geldikçe çalışanlar motivasyonlarını kaybetmeyecek, grup birlikteliğine daha fazla önem verecek ve belki de kaytarmak yerine diğer grup üyelerinin yardımına da koşacaklardır. Anlamlı görevlerde çalışırken yüksek düzeylerde çaba göstermek, bu çabaların somut performans çıktılarına çok az etkisi olsa ya da hiç etkisi olmasa bile, bireysel tatmine, grup tarafından onaylanmaya ve diğer önemli çıktılara yol açabilmektedir (Ilgın, 2010:116).

Bu noktada çalışanlarca işin anlamlı hale gelmesi için yöneticilere önemli görevler düşmektedir. İşin amaç ve hedefleri çalışanların değer ve idealleri ile çelişmemeli bilakis bunlar arasında gerekli uyum sağlanmalıdır. İşin yapılmaya değer bir iş olduğu anlatılmalı ve işin başarıldığında bireyin kendisinin, işletmesinin ve toplumun neler kazanacağı ifade edilmelidir. Aksine işin önemsenmediği ve başarılı bir şekilde yapılamadığında ise nelere mal olacağ çalışanı rencide ve tehdit etmeden anlatılmalıdır. Diğer taraftan bireyleri uyaracak çeşitli ödüller vasıtasıyla bireylerin motivasyonu arttırılabilir ve böylece işler daha anlamlı kılınabilir. Yöneticilerin çalışanları kararlara katması da çalışanları heyecanlandırabilir. Bireylerin kendileri tarafından alınan veya ortaklaşa alınan kararlar işi daha anlamlı hale getirebilir. Aldıkları kararların olumlu sonuçlarını görmek isteyen çalışanlar işe daha fazla anlam yükleyebilir ve çabalarını eksiltmeden görevlerini yerine getirebilirler. Bu ve benzeri şekilde işleri daha anlamlı hale getirerek yapılan psikolojik güçlendirme faaliyetleri sonucunda çalışanlardan sosyal kaytarma davranışlarını daha az göstermeleri beklenebilir.

$\mathrm{Bu}$ araştırmadan elde edilen diğer bulgulara göre psikolojik güçlendirmenin özerklik, yetkinlik ve etki boyutları sosyal kaytarmayı anlamlı olarak etkilememektedir. Aynı şekilde alt boyutların oluşturduğu bir bütün olarak da değerlendirilen psikolojik güçlendirme, sosyal kaytarmayı azaltma yönünde bir eğilim göstermemektedir. Bu bulgular sadece bu çalışmadan elde edilen verilere yöneliktir ve bu değişkenlerin kaytarmayı hiçbir zaman etkilemeyeceği anlamına gelmemektedir. Daha kapsamlı araştırmalarda daha farkı sonuçlara ulaşmak her zaman mümkündür. İleride araştırmacıların daha farklı sektörlerde, bölgelerde, ülkelerde ve daha fazla sayıda çalışan üzerinde derinlemesine araştırmalar yapması daha doğru sonuçlara varmamızı sağlayacaktır.

Literatürde psikolojik güçlendirmenin sosyal kaytarma ile ilişkisini inceleyen araştırmalara rastlanılmaması, araştırma sonuçlarının diğer araştırmalarla karşılaştırılmasına olanak vermemiştir. Dolayısıyla mevcut bulguların farklı çalışmaların bulgularıyla örtüşen veya örtüşmeyen yönlerini ortaya koyma imkânı olmamıştır. Diğer taraftan bu çalışmada sosyal kaytarma olumsuz ve istenmeyen bir davranış olarak ele alınmıştır. Fakat bazı durumlarda sosyal kaytarma olumlu sonuçlar da doğurabilir örneğin; bireysel hareket etmeyi tercih eden çalışanların bireysel çalışma imkânı elde ederek performanslarını arttırmaları, başkalarının görevlerini de yerine getirme yoluyla bireylerin farklı işlerde yetkinlik kazanması veya ekip ruhuna uymayan üyelerin kaytarmaları suretiyle grupsal faaliyetlere zarar vermesinin önüne geçilmesi gibi. Eğer sosyal kaytarmanın nadiren bile olsa böyle faydalarının olacağı öngörülüyorsa, psikolojik güçlendirme amacıyla işlerin çalışanlarca gereğinden fazla anlamlandırılmasının önüne geçilebilir.

\section{KAYNAKÇA}

Aggarwal, P., \& O'Brien, C. L. (2008). Social loafing on group projects: Structural antecedents and effect on student satisfaction. Journal of Marketing Education. 30,3:255-264.

Aktaş, R. (2003). Mali Başarısızlığın Öngörülmesi: İstatistiksel Yöntemler ve Yapay Sinir Ağı Karşılaştırılması. Ankara Üniversitesi SBF Dergisi, 58(04).

Alnuaimi, O. A., Robert, L. P., \& Maruping, L. M. (2010). Team size, dispersion, and social loafing in technologysupported teams: A perspective on the theory of moral disengagement. Journal of Management Information Systems, 27(1), 203-230.

Altman, E.I. (1968). Financial Ratios, Discriminant Analysis and the Prediction of Corporate Bankruptcy. The Journal of Finance, 23(4):589-609.

Arevalillo-Herráez, M. (2014). Impact evaluation of reactive assessment strategies to address social loafing by promoting student cooperation and encouraging mutual support. Innovations in Education and Teaching International, 51(5): 523-532.

Arslantaş, C. C. (2007). Güçlendirici lider davranışının psikolojik güçlendirme üzerindeki etkisini belirlemeye yönelik görgül bir araştırma, Anadolu Üniversitesi Sosyal Bilimler Dergisi, 7 (2): 227-240. 
Ashforth, B.E. (1989). The experience of powerlessness in organisations. Organizational Behavior and Human Decision Processes, 43(2): 207-242.

Besterfield, D. H., Besterfield, C., Besterfield, G. H. \&Besterfield-Sacre, M. (1999). Total Quality Management, Second Edition, Prentice Hall: USA.

Bolin, A. U., \& Neuman, G. A. (2006). Personality, process, and performance in interactive brainstorming groups. Journal of Business and Psychology. 20(4): 565-584.

Charbonnier, E., Pascal, H., Brauer, M., \& Monteil, J. M. (1998). Social loafing and self beliefs: People's collective effort depends on the extent to which they distinguish them- selves as better than others. Social Behavior and Personality, 26(4): 329-340.

Conger, J.A., \& Kanungo, R.N., (1988). The Empowerment Process: Integrating Theory And Practice, The Academy of Management Review, 13(3)

Doğan, S. (2006). Büyük Ölçekli işletmelerde insan kaynakları yöneticilerinin güçlendirilmiş bir iş çevresi yaratmaya ne kadar istekli ve hazır olduklarının tespitine ilişkin bir araştırma. Yönetim ve Ekonomi: Celal Bayar Üniversitesi İktisadi ve İdari Bilimler Fakültesi Dergisi, 13(2): 165-189.

Doğan, S. (2003). Personel Güçlendirme. Sistem Yayıncılık, İstanbul.

Doğan, S. ve Demiral, Ö. (2009). Örgütsel Bağlılığın Sağlanmasında Personel Güçlendirme ve Psikolojik Sözleşmenin Etkisine İlişkin Bir Araştırma. Erciyes Üniversitesi İktisadi ve İdari Bilimler Fakültesi Dergisi, 32(48): 47-80.

Dommeyer, C.J. (2007). Using the diary method to deal with social loafers on the group project: Its effects on peer evaluations, group behavior, and attitudes. Journal of Marketing Education 29(2): 175-88.

Eade, V. H. (1993). Human Resource Management in the Hospitality Industry, Gorsuch Scarisbrick Publishers: Arizona.

Elazı̆̆ Ticaret ve Sanayii Odası, http://www.elazigtso.org.tr/Parca/DosyaVeBelgeYonetimi/Upload/Elazig_ilinin_ekonomik_gelismesi.pdf, Erișim Tarihi: 16.04.2015

Emet, C. (2006). Personel Güçlendirme Algıları ile Örgütsel Kültür Arasındaki İlişkinin Bankacılık Sektöründe Ampirik Olarak Incelenmesi. Yayımlanmamış Yüksek Lisans Tezi, Dumlupınar Üniversitesi Sosyal Bilimler Enstitüsü, Kütahya

George, J. M. (1992). Extrinsic and instrinsic origins of perceived social loafing in organizations. Academy of Management Joumal, 35: 191-202.

Göktan, E. (1981). Muhasebe Oranlan Yardımıyla ve Diskriminant Analizi Tekniğini Kullanarak Endüstri Işletmelerinin Mali Başarısızlı̆̆ının Tahmini Üzerine Amprik Bir Araştırma (Basılmamış Doçentlik Tezi)

Hales, C., Klıdas, A. (1998). Empowerment in Five-Star Hotels: Choice, Voice or Rhetoric?. Contemporary Hopitality Management, 10(3):88-95

Harkins, S. G. \& Petty, R. E. (1982). Effects of task difficulty and task uniqueness on social loafing. Journal of Personality and Social Psychology, 43:1214-1229.

Hart, J. W., Karau, S. J., Stasson, M. F., \& Kerr, N. A. (2004). Achievement motivation, expected coworker performance, and collective task motivation: Working hard or hardly working? Journal of Applied Social Psychology. 34(5): 984-1000

Høigaard, R., Fuglestad, S., Peters, D.M., Cuyper, D., Backer, M. \& Boen, F. (2010). Role Satisfaction Mediates the Relation between Role Ambiguity and Social Loafing among Elite Women Handball Players. Journal of Applied Sport Psychology, 22, 408-419.

Hung, T. K., Chi, N. W., \& Lu, W. L. (2009). Exploring the relationships between perceived coworker loafing and counterproductive work behaviors: The mediating role of a revenge motive. Journal of Business and Psychology. 24(3): 257-270.

Ilgın, B. (2010). Örgütsel Vatandaşlık Davranışlarının Oluşumunda ve Sosyal Kaytarma İle İlişkisinde, Duygusal Zeka ve Lider Üye Etkileşiminin Rolü. Yayınlanmamış Doktora Tezi Hacettepe Üniversitesi Sosyal Bilimler Enstitüsü, Ankara.

Ilgın, B. (2013). Toplumsal Bir Hastalık: Sosyal Kaytarma. Uşak Üniversitesi Sosyal Bilimler Dergisi, 2013(15).

Jefkins, F. (1995). Public Relation Techniques, 2. Edition, Oxford: Butterworth-Heinemann Ltd.

Jones, G. R. (1984). Task visibility, free-riding and shirking: Explaining the effect of structure and technology on employee behavior. Academy of Management Review, 9:684-695.

Kanten, P. (2014). İşyeri Nezaketsizliğinin Sosyal Kaytarma Davranışı ve İşten Ayrılma Niyeti Üzerindeki Etkisinde Duygusal Tükenmenin Aracılık Rolü.Aksaray Üniversitesi İktisadi ve İdari Bilimler Fakültesi Dergisi, 6(1):1126.

Karau, S. J. \& Williams, K. D. (1993). Social loafing: A meta-analytic review and theoretical integration. Journal of Personality and Social Psychology, 65:681-706.

Karau, S. J. \& Williams, K. D. (1997). The effects of group cohesiveness on social loafing and social compensation. Group Dynamics: Theory, Research and Practice, 1:156-168.

Khany, R., \& Tazik, K. (2015). On the Relationship Between Psychological Empowerment, Trust, and Iranian EFL Teachers' Job Satisfaction The Case of Secondary School Teachers. Journal of Career Assessment, 1-18 
Kravitz, D. A., \& Martin, B. (1986). Ringelmann rediscovered: The original article. Journal of Personality and Social Psychology, 5, 936-941.

Kugihara, N. (1999). Gender and social loafing in Japan. Journal of Social Psychology. 139(4): 516-526.

Latane, B., Williams, K. D. \& Harkins, S. (1979). Many Hands Make the Light the Work: The Causes and Consequences of Social Loafing. Journal of Personality and Social Psychology, 37:822-833.

Latane', B. (1981). The psychology of social impact. American Psychologist, 36:343-356.

Lee, M. \& Koh, J. (2001). Is Empowerment Realy a New Concept? International Journal of HRM, 12 (4):684-695.

Liden, R. C., Wayne, S. J., Jaworski, R. A. \& Bennett, N. (2004). Social loafing: A field investigation. Journal of Management, 30(2):285-304.

Luthans, E. (1995). Organizational Behavior, Literatür Yayınc1lık, İstanbul.

MALORSA (Malatya Organize Sanayii Bölgesi), http://malorsa.org.tr/yazi.asp?id=1, Erişim Tarihi: 15.04.2015

Manz, C. C. \& Angle, H. (1986). Can group self-management mean a loss of personal control: Triangulating a paradox. Group \& Organization Studies, 11:309-334.

Mirzehanlı, R. (2001). Çalışanların Güçlendirilmesi ve Uygulamalardaki Eğilimlerin Araştırılması, Yayınlanmamış Yüksek Lisans Tezi, Gebze Yüksek Teknoloji Enstitüsü Sosyal Bilimler Enstitüsü, Kocaeli.

Morgeson, F. P., Reider, M. H., \& Campion, M. A. (2005). Selecting individuals in team settings: The importance of social skills, personality characteristics, and teamwork knowl- edge. Personnel Psychology, 58(3): 583-611.

Nunnaly, J. (1978). Psychometric theory. New York. McGraw-Hill.

Özdoğan, F. B. \& Tüzün, İ.K. (2007). Öğrencilerin Üniversitelerine Duydukları Güven Üzerine Bir Araştırma, Kastamonu Eğitim Dergisi, 15(2), 639-650: 644)

Petty, R. E., Harkins, S. G., \& Williams, K. (1980). The effects of group diffusion of cognitive effort on attitudes: An information-processing view. Journal of Personality and Social Psy-chology. 38: 81-92.

Ringelmann, M. (1913). Recherches sur les moteurs animés: Travail de l'homme [Research on animate sources of power: The work of man], Annales de l'Institut National Agronomique, 2nd series, 12:1-40.

Rothwell, J. D. (2004). In the Company of Others. New York. McGraw-Hill.

Smith, B. N., Kerr, N. A., Markus M. J., \& Stasson, M. F. (2001). Individual differences in social loafing: Need for cognition as motivator in collective performance. Group Dynamics: Theory. Research, and Practice. 5(2): 150158.

Somuncuoğlu, A.B. (2013), Psikolojik Güçlendirme ve İş Tatmini Arasındaki İlişki ve Bir Uygulama. Yayımlanmamış Yüksek Lisans Tezi, İstanbul Üniversitesi Sosyal Bilimler Enstitüsü, İstanbul.

Spreitzer, G. M. (1995a). An Emprical Test of a Comprehensive Model of Intrapersonal Empowerment in the Workplace. American Journal of Community Psychology, 23(5):601-629.

Spreitzer, G. M. (1995b). Psychological Empowerment in the Workplace: Dimensions, Measurement, and Validation, The Academy of Management Journal, 38(5):1442-1465.

Stark, E. M., Shaw, J. D., \& Duffy, M. K. (2007). Preference for Group Work, Winning Orientation, and Social Loafing Behavior in Groups. Group \& Organization Management, 32(6): 699-723.

Steiner, I. D. (1972). Group process and productivity. NY: Academic Press.

Streiner, D. (2003). Starting at the beginning: an introduction to coefficient alpha and internal consistency. Journal of personality assessment.;80:99-103.

Şen, Y. (2008). Dönüşümcü Liderliğin Psikolojik Güçlendirme ve Örgütsel Bă̆lllık Üzerindeki Etkilerini Belirlemeye Yönelik Bir Araştırma. Yayınlanmamış Yüksek Lisans Tezi, İstanbul Üniversitesi Sosyal Bilimler Enstitüsü, İstanbul.

Şeşen, H., \& Kahraman, Ç. A. (2014). İş Arkadaşlarının Sosyal Kaytarmasının, Bireyin İş Tatmini, Örgütsel Bağlılık ve Kendi Kaytarma Davranışlarına Etkisi. Işs ve Insan Dergisi, 1(1): 43-51.

Tazegül, P. (2001). Çalışanların Güçlendirilmesi ve Hizmet Sektöründe Bir Vaka Çalışması Uygulaması, Yayınlanmamış Yüksek Lisans Tezi, Gebze Yüksek Teknoloji Enstitüsü Sosyal Bilimler Enstitüsü, Kocaeli.

Thomas, K.W. \& Velthouse, B.A. (1990). Cognitive Elements of Empowerment: An Interpretive Model of Intrinsic Task Motivation, Academy of Management Review, 15(4):666-681.

Thompson, B., \& Thornton, B. (2007). Exploring Mental-State Reasoning as a Social-Cognitive Mechanism for Social Loafing in Children. The Journal of social psychology, 147(2), 159-174.

Tolay, E., Sürgevil, O., \& Topoyan, M. (2012). Akademik çalışma ortamında yapısal ve psikolojik güçlendirmenin duygusal bağlılık ve iş doyumu üzerindeki etkileri. Ege Akademik Bakış, 12(4): 449-465.

Webb N (1997) Assessing students in small collaborative groups. Theory into Practice 36(4): $205-13$.

Williams, K. D. \& Karau, S. J. (1991). Social loafing and social compensation: The effects of expectations of co-worker performance. Journal of Personality and Social Psychology, 61:570-581.

Williams, K. D., Harkins, S. G. \& Latane, B. (1981). Identifiability as a deterrent to social loafing: Two cheering experiments. Journal of Personality and Social Psychology, 40:303-311.

Williamson, O. (1975). Markets and hierarchies. New York: Free Press. 